\title{
Mesenchymal stem cells therapy in companion animals: useful for immune- mediated diseases?
}

Inês Esteves Dias ${ }^{1}$, Pedro Olivério Pinto ${ }^{1,2}$, Luís Carlos Barros ${ }^{1}$, Carlos Antunes Viegas ${ }^{3,4,5}$, Isabel Ribeiro Dias $3,4,5$ and Pedro Pires Carvalho ${ }^{1,6^{*}}$ (1)

\begin{abstract}
Mesenchymal stem cells are multipotent cells, with capacity for self-renewal and differentiation into tissues of mesodermal origin. These cells are possible therapeutic agents for autoimmune disorders, since they present remarkable immunomodulatory ability.

The increase of immune-mediated diseases in veterinary medicine has led to a growing interest in the research of these disorders and their medical treatment. Conventional immunomodulatory drug therapy such as glucocorticoids or other novel therapies such as cyclosporine or monoclonal antibodies are associated with numerous side effects that limit its long-term use, leading to the need for developing new therapeutic strategies that can be more effective and safe. The aim of this review is to provide a critical overview about the therapeutic potential of these cells in the treatment of some autoimmune disorders (canine atopic dermatitis, feline chronic gingivostomatitis, inflammatory bowel disease and feline asthma) compared with their conventional treatment.

Mesenchymal stem cell-based therapy in autoimmune diseases has been showing that this approach can ameliorate clinical signs or even cause remission in most animals, with the exception of canine atopic dermatitis in which little to no improvement was observed.

Although mesenchymal stem cells present a promising future in the treatment of most of these disorders, the variability in the outcomes of some clinical trials has led to the current controversy among authors regarding their efficacy. Mesenchymal stem cell-based therapy is currently requiring a deeper and detailed analysis that allows its standardization and better adaptation to the intended therapeutic results, in order to overcome current limitations in future trials.
\end{abstract}

Keywords: Mesenchymal stem cells, Immunomodulation, Canine atopic dermatitis, Feline chronic gingivostomatitis, Inflammatory bowel disease, Feline asthma

\section{Background}

Regenerative medicine results from the need to treat diseases for which modern medicine has no accessible or effective treatment [1]. This kind of therapy relies on the use of cells as therapeutic agents capable of regenerating damaged organs and tissues [2, 3]. Despite the wide range of potential candidates that can be applied in these therapies, stem cells are the ones that have been

\footnotetext{
* Correspondence: pedro.carvalho@euvg.pt; hello@vetherapy.co

'CIVG - Vasco da Gama Research Center, Vasco da Gama University School,

Av. José R. Sousa Fernandes 197, Campus Universitário - Bloco B, Lordemão, 3020-210 Coimbra, Portugal

Getherapy, 479 St, San Francisco, CA 94103, USA

Full list of author information is available at the end of the article
}

continuously addressing greatest expectations within the scientific community [4].

In traditional textbooks, stem cells were believed to be at the origin of all main types of tissue and it was also stated that differentiation occurred unidirectionally and irreversibly, once they were totally or partially differentiated in a certain type of cell, they could not differentiate again. Currently, it is well known that these cells are characterized by their plasticity and can undergo transformation more than what was originally thought [5]. In fact, stem cells are now considered unspecialized cells that share two important characteristics, they can selfrenew indefinitely or differentiate into more mature cells with specialized functions $[1,6]$. 
These cells can be classified in Embryonic Stem Cells (ESCs), Induced Pluripotent Stem Cells (iPSCs) and Mesenchymal Stem Cells (MSCs), which differ in origin, plasticity, differentiation potential and in risk of tumorigenesis. The process of differentiation of stem cells is represented in Fig. 1, and the classification of these cells in Table 1.

ESCs are totipotent cells. They are able to originate any type of cells from the three germinal layers (endoderm, mesoderm, ectoderm) as well as extraembryonic annexes (e.g. placenta and umbilical cord). Despite their enormous potential, their application in cell therapy carries a series of inconveniences. Obtaining these embryonic cells is a much more complex and expensive procedure than other types of stem cells, there is a larger risk of tumorigenesis and immune rejection and there are also moral and legal restrictions to its use $[4-6,9,10]$.

iPSCs are obtained from adult cells transformation which are modified in laboratory to pluripotent cells. Similarly to ESCs, iPSCs also present a high risk of tumorigenesis, limiting its therapeutic use [11, 12].

MSCs are multipotent cells (partially specialized cells capable of generating a certain number of cell types, presumably from its own original germinal layer) with self-renewal capacity $[3,6,13,14]$. They derive from the embryonic layer of the mesoderm and under certain conditions they can differentiate into osteoblasts, chondrocytes, myocytes, $\beta$-pancreatic islets cells, neural cells, among others [15]. Adult MSCs have been shown to be nontumourigenic and nonimunogenic [4]. These cells were first successfully isolated from bone marrow by Friendstein and co-workers (1970) [16], and since then, the interest in their therapeutic potential has grown, leading to the emergence of new researches. These cells have been used in different veterinary hospitals as a therapeutic tool, however, there is yet no standard regulatory pathway for their use from the Food and Drug Administration (FDA) or the European Medicines Agency (EMA), since more data and definition of standardized protocols are required [6].

Currently, MSCs are mainly used in veterinary medicine to treat musculoskeletal system disorders, considering their ability to differentiate into various tissues of mesodermal origin. In human medicine, therapies with MSCs are mostly used in the treatment of immune-mediated inflammatory and ischemic diseases [17, 18]. Moreover, studies to evaluate the therapeutic potential of stem cells in humans would benefit from more companion animals models, since some diseases affect both alike, making them good preclinical models $[11,19]$.

The increase of immune-mediated diseases in veterinary medicine (such as canine atopic dermatitis, feline chronic gingivostomatitis, inflammatory bowel disease, feline asthma, among others) [20-22] has led to a growing interest in the research of these disorders and their medical treatment. Conventional immunomodulatory drug therapy such as glucocorticoids, or other novel therapies such as cyclosporine or monoclonal antibodies, are associated with numerous side effects that limit its long-term use [23], leading to the need for more effective and safe therapeutic strategies' development.

The aim of this review is to provide a critical overview about the therapeutic potential, current status and future prospects of these cells in the treatment of immunemediated diseases in veterinary medicine, pointing out the advantages and disadvantages of a treatment drawn with stem cells in comparison to other conventional treatments of these particular diseases.

\section{Mesenchymal stem cells Mesenchymal stem cells characterization}

MSCs, also known as mesenchymal stromal cells, are multipotent cells, of non-hematopoietic origin, with selfrenewal capacity, present in connective tissue throughout the body [14, 24]. They have been isolated from different adult tissues (such as bone marrow, adipose tissue, peripheral blood, muscle, dental pulp, periodontal ligament, articular cartilage, periosteum) and from extraembryonic tissues (for instance umbilical cord blood, membrane and amniotic fluid) [4].

In veterinary medicine, MSCs are obtained mainly from adipose tissue and bone marrow (BM), taking into consideration their location and harvesting procedure $[3,6,25]$. Although BM represents an abundant source

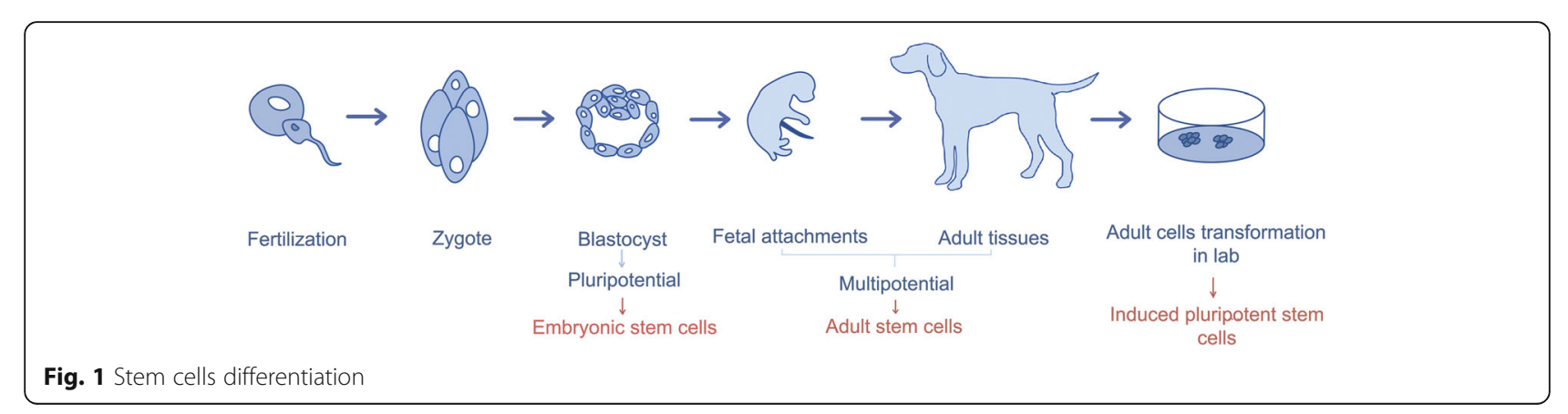


Table 1 Stem cells classification $[1,3,4,7,8]$

\begin{tabular}{llll}
\hline & ESC & iPSC & MSC \\
\hline Origin & $\begin{array}{l}\text { Derived from the inner cell mass } \\
\text { of the pre-embryonic blastocyst }\end{array}$ & $\begin{array}{l}\text { Derived from reprogrammed donor } \\
\text { cells by exposure to transcription factors }\end{array}$ & $\begin{array}{l}\text { Derived from tissues of endodermal, } \\
\text { mesodermal and ectodermal lineages }\end{array}$ \\
Plasticity & Totipotents & Pluripotents & Multipotents \\
Differentiation potential & Endodermal, mesodermal and & Endodermal, mesodermal and & Mesodermal tissues \\
& ectodermal tissues & ectodermal tissues & No (minimal) \\
Risk of tumorigenesis & Yes & Yes &
\end{tabular}

of MSCs, harvesting this tissue is more invasive and requires younger donors, making adipose tissue a first choice [3, 10].

MSCs play an important role in the regulation of the immune system. Moreover, they are relatively easy to isolate and can be expanded in culture. Although MSCs are not part of the immunologic system according to the prearranged definitions [26], they interact with all kinds of immunologic cells. They produce a great variety of antiinflammatory and pro-inflammatory factors, among which are cytokines, chemokines and prostaglandins, which target immune cells and affect their function [24]. It is noteworthy that MSCs are considered safe, with minimal or non-teratogenic risk and can be used for tissue repair and regeneration [14].

These cells present remarkable pleiotropic properties, including antiapoptosis, angiogenesis, growth factor production, antifibrosis and the ability to migrate toward injury sites through chemiotaxis [3, 6, 27]. The MSCs ability to differentiate into parenchymal cells of the mesoderm has become one of the main criteria to define their identity. Although recent data suggest that under appropriate culture conditions MSCs may also be induced to transdifferentiate into ectoderm (epithelia and neurons) and endoderm cells (lung cells and gut epithelial cells) $[14,27]$.

\section{Minimal criteria for defining mesenchymal stem cells}

The pleiotropic nature of MSCs presents a challenge in their identification [27]. In order to create a broader consensus on the universal characterization of MSCs, and facilitate the exchange of data among investigators, the International Society for Cellular Therapy formulated minimal criteria for defining MSCs. These criteria include plastic adherence, capability for differentiation towards osteoblasts, adipocytes and chondroblasts under standard in vitro conditions, cell surface expression of CD73, CD90, CD105 and absence of hematopoietic stem cell markers (CD14, CD19, CD34, MHC-II, etc.) [4, 6, 28-30] (Fig. 2).

Although stem cell scientists continue to develop more stringent criteria, these basic criteria are generally accepted as the baseline for declaring a cell type as a MSC [5].

\section{Origin of mesenchymal stem cells}

The origin of MSCs and their development is not yet fully understood $[6,31]$. Although MSCs had formerly been isolated from bone marrow, they have already been withdrawn from the stroma of multiple organs and tissues including the adipose tissue, the tonsils, the umbilical cord, the skin and the dental pulp. Crisan and co-workers (2008) suggest as hypothesis that MSCs generate from pericytes (Fig. 3). Pericytes are perivascular cells present in the microvasculature of every vascularized connective tissue. This group has identified pericytes in multiple human organs (skeletal muscle, pancreas, adipose tissue and placenta) based on the expression of cell markers: CD146, NG2 and PDGF-R $\beta$. They found out that these cells expressed typical MSCs markers and in a specific culture medium they could differentiate into myocytes, osteocytes, chondrocytes and adipocytes [27, 32, 33].

Although the study has not directly monitored the probable in vivo transition of the pericytes to MSCs, they recognized pericytes as potential progenitor cells to non BMSCs [27, 32]. In 2011 Feng et al. provided evidence that MSCs originate from pericytes as well as nonpericytes. This group conducted an experiment using genetic lineage tracing. They suggest that the contribution of pericytes to the origin of MSCs depends on the extent of vascularity and tissue growth kinetics. Therefore, in tissues with low vascularization (e.g., articular cartilage), the contribution of the pericyte to MSCs will be lower than in tissues with more extensive blood supply [34]. Nevertheless, on the regenerative medicine field this hypothesis does not gather everyone's consensus and acceptance.

\section{Interaction between mesenchymal stem cells and immune cells}

MSCs have two important effects on the immune system, including an anti-inflammatory and immune-enhancing response. These cells regulate immune responses such as altering antibody production by B-lymphocytes, shifting T-lymphocyte subtypes, and inducing immune tolerance to allogeneic transplants $[6,35]$. They release more than 200 bioregulatory products that have antimicrobial, immunomodulatory, antifibrotic, antiapoptotic, hematopoietic stem cells support, chemoattraction, angiogenesis, neuroprotective and mitogenic functions [4]. 


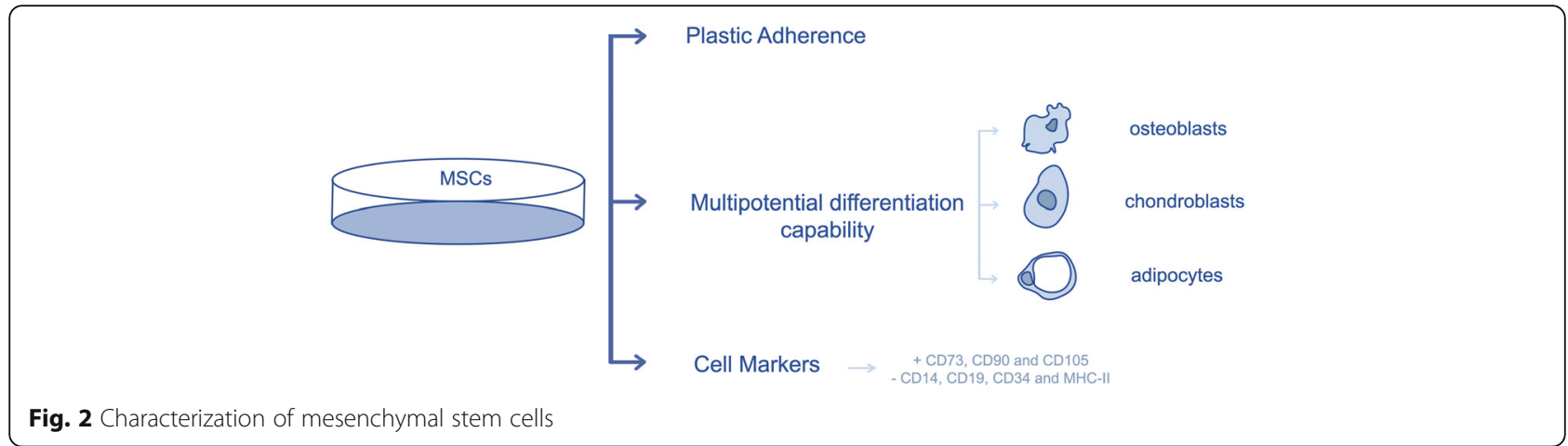

MSCs are capable of interacting with various types of immune cells, including $\mathrm{T}$ cells, B cells, natural killer (NK) cells, dendritic cells (DCs), macrophages/monocytes and neutrophils [36] affecting both the innate and humoral immune responses [35]. It is ambiguous whether MSCs should be classified as "immunosuppressive," suggesting a nonspecific downregulation of the immune system, or rather if they induce an "immune tolerance," suggesting a more specific suppression of aberrant immune responses. What seems to be clear is the fact that the MSCs' immunomodulatory ability depends on several factors such as MSCs activation, MSCs tissue of origin, MSCs doses, MSCs time of administration, and MSCs contact with cells of the immune system [35].

Although the underlying mechanisms of MSCs immunomodulation have yet to be elucidated, it is believed that immunomodulation first takes place through paracrine effects by producing immunomodulatory mediators, including nitric oxide (NO), indoleamine 2,3dioxygenase (IDO) [37], transforming growth factor- $\beta$ (TGF- $\beta$ ), hepatocyte growth factor (HGF), hemoxygenase (HO), interleukin (IL)-6 and prostaglandin $E_{2}$ $\left(\mathrm{PGE}_{2}\right)$, and they may also occur through cell-cell direct contact $[6,15,38,39]$ (Fig. 4).

\section{Mechanisms of mesenchymal stem cells suppression of innate immune cells}

The innate immune cells play an important role in the organism homeostasis and are the first defence line against invading pathogens such as viruses and bacteria. The cells belonging to this system respond promptly in a non-specific form to pathogens [27]. This defence response is based on inflammation. During inflammation there are certain changes in the tissues caused by microbial invasion or tissue damage, resulting in the increase of blood flow and the local accumulation of cells, which may attack or destroy invaders. The innate immunity has a cellular defence line (neutrophils, monocytes/macrophages, DCs and NK cells) and an enzymatic defence line (these enzymes form what is known as the complement system) [40].

MSCs act on the immunity system through three main mechanisms. One of those mechanisms consists in activating proinflammatory monocytes and macrophages. In the presence of MSCs and their soluble factors (IL-6, $\mathrm{PGE}_{2}$, TGF- $\beta, \mathrm{HGF}$ ), the $\mathrm{M}_{1}$ classic macrophages possessing proinflammatory functions, become active in $\mathrm{M}_{2}$ anti-inflammatory macrophages, which are characterized by high expression of IL-10, low production of tumour
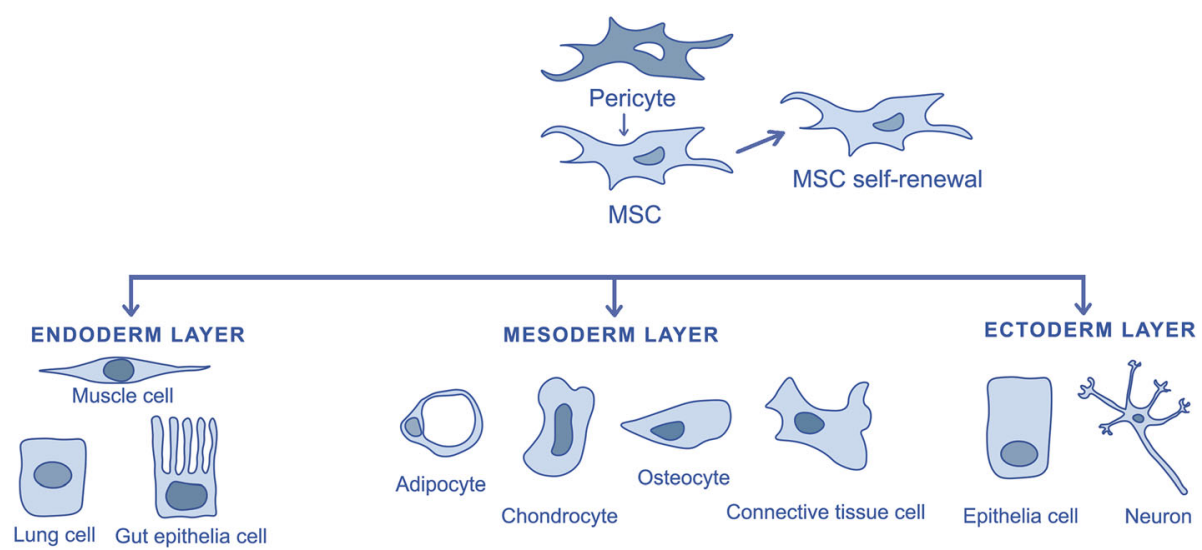

Fig. 3 Possible origin of mesenchymal stem cells and their differentiation into mesodermal, endodermal and ectodermal cells 


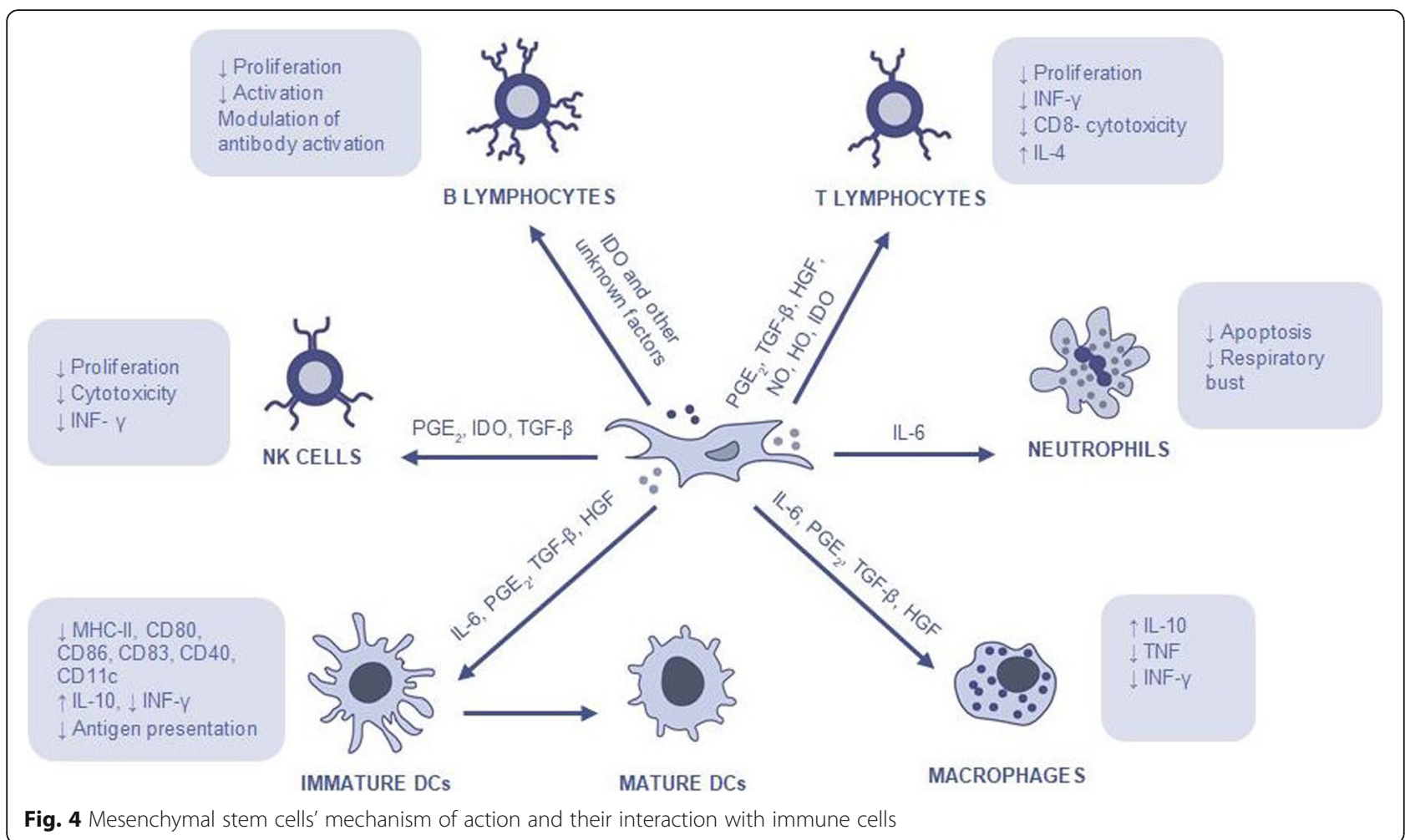

necrosis factor (TNF) and low production of interferon gamma (IFN-y) [38, 41, 42].

MSCs can also inhibit the differentiation of monocytes into mature DCs by releasing soluble factors such as IL6 , $\mathrm{PGE}_{2}$, TGF- $\beta$, HGF. These tolerogenic DCs produce high levels of IL-10 and have low capacity to stimulate proliferation of allogeneic $\mathrm{T}$ cells in a mixed lymphocyte reaction [38, 43].

Finally, MSCs inhibit NK cells proliferation and cytotoxicity, which can require cell-to-cell contact or can be mediated by soluble factors, including mainly $\mathrm{PGE}_{2}$ and IDO, but also TGF- $\beta[14,38,44]$.

\section{Mechanisms of mesenchymal stem cells suppression of adaptive immune cells}

The acquired immune system is responsible for recognizing foreign invaders, destroy them and retain the memory after first antigen contact. If the animal finds the same antigen a second time, the immunologic system will respond in a more effective and prompt way. The acquired immune system is based on two main branches. One is called "humoral immune response" and is mediated by B-lymphocytes that produce antibodies against exogenous invaders. The other major branch is called "cell-mediated immune response" and is mediated by T-lymphocytes which act directly against endogenous invaders that invade cells [40].

MSCs are able to suppress the proliferation of $\mathrm{T}$ cells and modulate their response through the secretion of several soluble factors $\left(\mathrm{PGE}_{2}\right.$, TGF- $\beta$, HGF, $\mathrm{NO}, \mathrm{HO}$, IDO) or through cell-to-cell contact. In an environment composed by strong inflammatory components, MSCs have the ability to change the T-helper 1 (Th1) proinflammatory profile into a T-helper 2 (Th2) anti-inflammatory profile $[23,38]$.

The effects of MSCs on B cells remains contradictory although there is evidence that MSCs have close interactions with B cells. MSCs are able to inhibit B cell proliferation through cell-to-cell contact and through an arrest in the G0/G1 phase of the cell cycle [45]. Moreover, MSCs suppress plasma cell differentiation induced by allostimulation and immunoglobulin (Ig) production. Studies have also suggested that, although MSCs are able to suppress B cells which are activated by several stimuli, they are incapable of modulating naive or memory B cells $[14,23,38,46]$.

Concluding, MSCs regulate immune responses such as altering antibody production by B-lymphocytes, shifting T-lymphocyte subtypes, and inducing immune tolerance to allogeneic transplants due to the lack of MHC-II expression and co-stimulatory molecules such as CD40, CD80 and CD86, since they escape the recognition and action of $\mathrm{T}$ cells and NK receptors $[6,35]$. However, their immunomodulatory capacity is not yet fully understood and there are still variable results concerning immunomodulatory therapies with MSCs [15]. A deeper understanding of the mechanism through which the MSCs deriving from veterinary species modulate 
inflammation and contribute to the healing process, will beneficiate human beings as well as animals [23].

\section{Therapeutic strategies with mesenchymal stem cells in immune-mediated disorders \\ Canine atopic dermatitis}

Atopic dermatitis (AD) is the most frequent dermatopathy in dogs and shares many characteristics with the human disease $[4,19]$. This chronic multifactorial disorder is associated with breed predilections, polymorphisms at specific gene loci, altered gene expression and specific allergens [47-49]. It is characterized by a dysfunction of the skin barrier due to changes in lipid (ceramides) and protein (filaggrin) composition, modifications in the stratum corneum and loss of water from the transepidermis, which predisposes to a higher allergen penetration [4, 47-49]. The skin of atopic dogs tends to produce less antimicrobial agents (defensins, cathelicidins, etc.) usually leading to secondary infection. Infectious agents such as Staphylococcus pseudointermedius, Staphylococcus intermedius and Malassezia pachydermatis worsen the clinical presentation of $\mathrm{AD}$ (pyoderma and otitis) and induce a phenomena of allergic sensitisation with large amounts of lgE antibodies $[4,50]$. When allergenic load overcomes a certain threshold, mast cells will activate leading to consequent allergic response and its clinical presentation.

According to the 2015 updated guidelines from the International Committee on Allergic Diseases of Animals (ICADA), the treatment of acute and chronic AD is based on three key points, as described in Table 2 [51].

With the aim of preventing the reappearance of clinical signs, some strategies can be developed, such as avoidance of known flare factors, consideration of proactive intermittent topical glucocorticoid therapy and implementation of allergen-specific immunotherapy, if feasible [51].

Some adverse effects are seen with these treatments, especially with its long-term use. Unfortunately, due to AD pathophysiology, glucocorticoids are frequently needed. Systemic administration of these drugs might result in polyuria, polydipsia, polyphagia, changes of behaviour (including aggressiveness) and, depending on the initial dose, iatrogenic hyperadrenocorticism [51].

Another therapy with a canonized anti-canine IL-31 monoclonal antibody - lokivetmab (ZTS-00103289) - has recently demonstrated efficacy in reducing pruritus in canine atopic dermatitis trials $[52,53]$. This monoclonal antibody is administrated subcutaneously in the animal and binds specifically to circulating IL-31, thereby inhibiting its binding to the IL-31 receptor [52, 53]. However, its effects are still poorly understood.

Over the last few years, the immunomodulatory effect of MSCs therapy has been described in animal models and in human beings, showing a significant improvement in the clinical presentation by inhibiting the activation of
$\mathrm{T}$ and $\mathrm{B}$ cells and consequent release of anti-inflammatory cytokines (IL-10, TGF- $\beta$ ), by decreasing the proliferation of IL-4 and IFN, and by decreasing the production of $\operatorname{lgE}$ [4].

Hall et al. (2010) carried out a clinical trial with five AD canine patients (Table 3). All the patients were treated with a single dose of autologous adipose stem cells (ASCs). The dosage of intravenous (IV) $1 \times 10^{6}$ cells (1.3 million cells $/ \mathrm{kg}$ ) applied in this trial was substantially lower than the dosage applied in other trials and lower than the dosages usually applied in human trials $\left(\geq 2 \times 10^{6} / \mathrm{kg}\right.$ of body weight). Although the injections had been considered safe, no signs of progress were observed during this trial with the ASCs treatment [54].

Jiménez \& Guerrero (2017) have also published in the Clindervet journal a study on the use of MSCs in veterinary dermatology, where they report a successful case of canine $\mathrm{AD}$ with MSCs-based treatment. They obtained significant improvement in clinical signs with no complications mentioned [4].

\section{Feline chronic Gingivostomatitis}

Feline chronic gingivostomatitis (FCGS) is a severe, idiopathic, inflammatory oral disease characterized by severe inflammation of the gingiva, buccal mucosa and caudal oral mucosa, that affects approximately $0.7-10 \%$ of the general cat population [55-57]. The aetiology of FCGS is poorly understood, nonetheless it has been suggested that microbial factors and alterations in the innate immune response may play an important role in the pathogenesis of this disorder [58]. Researchers believe that the factor contributing the most to the development of this disorder is the presence of bacterial plaque and that the development of FCGS is due to an immune abnormality, specifically related to the inflammatory mediators produced by lymphocytes and plasma cells in response to infectious agents (e.g. feline calicivirus [FCV], feline leucemia $[\mathrm{FeLV}]$, feline herpesvirus, feline immunodeficiency virus [FIV] and Bartonella henselae). However, these infectious agents may not be responsible for the disease, and rather be mere contributors to the patient's morbidity in the healing phase of the treatment $[57,59]$. Histologically, the injuries in cats are characterized by an inflammation with lymphocytes, mostly effector $\mathrm{T}$ cells and B cells [22].

This disorder causes painful mucosal lesions that markedly reduce the quality of life. Clinical signs vary from pain and moderate to severe oral discomfort, inappetence, loss of weight, reduced grooming and ptyalism [21].

According to the Portuguese Association of Veterinarians Specialized in Companion Animals (APMVEAC), ${ }^{1}$ so far there is no treatment against FCGS that is 100\% 
Table 22015 updated guidelines of acute and chronic atopic dermatitis treatment [51]

\begin{tabular}{|c|c|c|}
\hline & Acute AD & Chronic AD \\
\hline Identification and avoidance of flare factors & $\begin{array}{l}\text { Elimination of allergenic flare factors } \\
\text { (fleas, food and environmental); } \\
\text { Evaluation of the use of antimicrobial } \\
\text { therapy if clinical signs of infection } \\
\text { with bacteria or yeast are present on } \\
\text { the skin or in the ears. }\end{array}$ & $\begin{array}{l}\text { Dietary restriction-provocation trials in dogs with } \\
\text { nonseason signs; } \\
\text { Implementation of an effective flea control regimen; } \\
\text { Performance of allergen-specific intradermal and/or } \\
\text { IgE serological tests to identify possible environmental } \\
\text { allergen flare factors; } \\
\text { Implementation of house dust mice or other allergen } \\
\text { control measures; } \\
\text { Evaluation of the use of antimicrobial therapy (terbinafine } \\
\text { or itraconazole once a day [SID] for two consecutive days } \\
\text { each week for } 3 \text { weeks to treat flares provoked or } \\
\text { exacerbated by Malassezia skin infections). }\end{array}$ \\
\hline $\begin{array}{l}\text { Improvement in skin and coat hygiene } \\
\text { and care }\end{array}$ & $\begin{array}{l}\text { Bathing with a non-irritating shampoo } \\
\text { containing lipids, complex sugars and } \\
\text { antiseptics or phytosphingosine, } \\
\text { raspberry oil and lipids. }\end{array}$ & $\begin{array}{l}\text { Bathing at least once weekly with a non-irritating shampoo } \\
\text { or an antiseborrheic/ antimicrobial shampoo and dietary } \\
\text { supplementation with essential fatty acids. }\end{array}$ \\
\hline Reduction of pruritus and skin lesions & $\begin{array}{l}\text { Topical glucocorticoids sprays for } \\
\text { localized lesions; } \\
\text { Oral glucocorticoids (prednisolone, } \\
\text { prednisone or methylprednisolone given } \\
\text { at } 0.5 \text { to } 1.0 \mathrm{mg} / \mathrm{kg} \text { per day SID or two } \\
\text { times a day [BID]) or oral oclacitinib } \\
\text { (0.4 to } 0.6 \mathrm{mg} / \mathrm{kg} \text { BID for up to } 14 \text { days) } \\
\text { for widespread or severe lesions. }\end{array}$ & $\begin{array}{l}\text { Topical glucocorticoids sprays for localized lesions; } \\
\text { Oral glucocorticoids (prednisolone, prednisone or } \\
\text { methylprednisolone given at } 0.5 \mathrm{mg} / \mathrm{kg} \text { SID or BID), oral } \\
\text { cyclosporine ( } 5 \mathrm{mg} / \mathrm{kg} \text { SID until satisfactory control of } \\
\text { clinical signs), oclacitinib (0.4 to } 0.6 \mathrm{mg} / \mathrm{kg} \text { BID for } 14 \text { days } \\
\text { and then SID) or injectable interferons (recombinant } \\
\text { canine interferon-gamma given subcutaneously [SC] at } \\
5.000-10.000 \text { units/kg three times weekly for four weeks } \\
\text { and then once weekly) for widespread or severe lesions. } \\
\text { These drugs should not be combined together in the } \\
\text { long term to reduce the risk of immunosuppression. }\end{array}$ \\
\hline
\end{tabular}

effective, and this may result in euthanasia of several affected cats. Approximately $70 \%$ of cats respond to standard treatment consisting of total or partial teeth extraction. The remaining $30 \%$ do not react to teeth extraction and require therapy with antibiotics, corticosteroids and other pain relief medication throughout their lives $[21,55]$.

A successful treatment requires the minimization of oral bacteria (Table 4), therefore the therapeutic plan should be started with the improvement of the animal's oral hygiene with professional veterinary dental cleaning with follow-up controls [57, 60].

All teeth with inflammation of the gingiva and adjacent mucosa should be removed, as well as teeth with dental resorption lesions and with advanced periodontal disease. Tooth extraction can be multiple or radical depending on affected teeth, and should begin with the removal of the premolar and molar teeth when affected. If incisive and canine mucous membrane is inflamed, these teeth should also be removed, leading to a radical extraction with removal of all teeth (Table 4). The transition to canned pet food (with an appetite stimulant if necessary) before the surgery is an important step to minimize mouth pain [57]. For the surgical approach, pain control with buprenorphine $(0.02 \mathrm{mg} / \mathrm{kg}$ sublingually three times a day [TID] or BID) and gabapentin

\footnotetext{
${ }^{1}$ Associação Portuguesa de Médicos Veterinários Especialistas em Animais de Companhia (APMVEAC)
}

(5-10 $\mathrm{mg} / \mathrm{kg}$ BID or SID) is recommended, and a nonsteroidal anti-inflammatory (NSAID) might also be applied (e.g. robenacoxib $1-2 \mathrm{mg} / \mathrm{kg}$ orally [PO] SID), during post-surgery. The use of systemic antibiotics instead of partial or total teeth extractions is unwise and only contributes to the patient's likely resistance to antibiotics [57].

The authors define gingivostomatitis refractory to dental extraction when there is no improvement of clinical signs up to 60 days after teeth removal, which comes as a considerable therapeutic challenge for the physician. In refractory situations treatment with anti-inflammatory or immunomodulatory therapies might be considered (Table 4) $[57,59,62]$.

ASCs therapy is another option increasingly used. The ability of MSCs to inhibit T-cell proliferation and induce T-cell anergy suggests that therapy with MSCs can be quite promising for the treatment of FCGS. Arzi et al. (2016) carried out a clinical trial with seven FCGS patients, non-responsive to radical teeth extraction and immunosuppressive therapies. Treatment was based on two IV administrations of $2 \times 10^{7}$ autologous ASCs $(\sim 5$ million cells $/ \mathrm{kg}$ ) with 3 to 4 weeks apart whose results are displayed on Table 5. The authors applied flow cytometry to compare CD8 expression with treatment reaction. It was found that cats with $<15 \% \mathrm{CD} 8 \mathrm{~T}$ cytotoxic cells (with low expression of those cells) were $100 \%$ responsive to therapy, while cats with $>15 \%$ did not react to treatment. Relative absence of CD8 cells 
Table 3 Clinical trial carried out with mesenchymal stem cells in canine atopic dermatitis

\begin{tabular}{llll}
\hline Specie (number) & Treatment & Results & Conclusion \\
\hline Dog (5) & $\begin{array}{l}\text { Single IV autologous ASCs } \\
(1.3 \text { million cells/kg) }\end{array}$ & $\begin{array}{l}\text { No benefits of ASCs } \\
\text { treatment were observed. }\end{array}$ & $\begin{array}{l}\text { The dosage of ASCs was lower than } \\
\text { employed in other studies. The results } \\
\text { are inconclusive. }\end{array}$ \\
\hline
\end{tabular}

may be a biomarker to predict the response to therapy using adipose stem cells [55].

In 2017 Arzi et al. carried out a similar trial using the same dosage and time spans in seven cats with FCGS, yet the therapy applied used allogeneic ASCs (results are displayed on Table 5). These results suggest that autologous therapy may be somewhat more effective, particularly in severely affected cats, and may cause improvement or complete remission of signs more rapidly than with allogeneic therapy [21].

\section{Inflammatory bowel disease}

Inflammatory bowel disease (IBD) is a chronic inflammatory enteropathy characterized by intestinal inflammation and persistent or frequent gastrointestinal signs, that do not respond to food trials or antimicrobial treatments, therefore requiring immunosuppressive treatment [63-65]. The aetiology of IBD in veterinary medicine is not fully understood, although there are similarities with human IBD (Crohn's disease and ulcerative colitis) [66]. Idiopathic IBD is the most common aetiology in dogs and cats possibly resulting from the breakdown of immunologic tolerance to luminal antigens (commensal bacteria and dietary components), most likely due to disruption of the mucosal barrier, dysregulation of the immune system, or disturbances in the microbiome, with upregulation of Toll-like Receptors (TLRs) [20, 22, 63, 67]. Genetic factors are likely to contribute to the pathogenesis of IBD [63].

Currently, there are no definitive guidelines for the treatment of IBD so it can undergo individual variability according to the patient's record (Table 6). The proposed treatment aims to reduce gastrointestinal signs (e.g. vomit and diarrhoea), increase appetite and weight, and reduce intestinal inflammation [63].

A dietary modification with limited antigen, highly digestible and with a single source of protein has been recommended. These exclusion diets may also help resolve any secondary sensitivities to dietary components that might have arisen after disruption of the mucosal barrier $[63,68]$.

Treatment with antimicrobials can be justified in IBD, partially to treat any secondary Small Intestinal Bacterial Overgrowth (SIBO) and partially because of the importance of bacterial antigens in the pathogenesis of IBD $[63,68]$. Metronidazole is the preferred drug for small animals [63].

Immunosuppressive medication with corticosteroids is the treatment of choice in most cases, although cushingoid side effects are common but transient as the dosage is reduced. Azathioprine is an alternative drug that has good steroid-sparing properties and is frequently used in dogs when IBD cannot be effectively managed with glucocorticoids or when the glucocorticoid dose has to be reduced. If there is still a poor response, cyclosporine is another alternative agent, because it inhibits the production of IL-2. However its efficacy has not yet been fully validated $[63,64,68]$.

The animal owners' decision to carry out a treatment for this chronic disease might be a concern because not every animal responds to treatment. For this reason, alternative approaches became necessary [22] Applying MSCs as an alternative treatment for IBD is still a very recent conception. However, the use of this therapy in clinical trials on human beings with inflammatory

Table 4 Conventional and immunomodulatory therapeutic approach to feline chronic gingivostomatitis

\begin{tabular}{|c|c|}
\hline & Feline Chronic Gingivostomatitis \\
\hline Teeth extraction & $\begin{array}{l}\text { All teeth with inflammation of the gingiva and adjacent mucosa should be removed, as well as teeth } \\
\text { with dental resorption lesions and with advanced periodontal disease }[21,55] \text {. }\end{array}$ \\
\hline Oral hygiene & Professional veterinary dental cleaning with follow-up controls $[57,60]$. \\
\hline Corticosteroids & $\begin{array}{l}\text { Prednisolone after tooth extraction (3-4 mg/kg SID during } 3 \text { to } 4 \text { weeks) [57, 59]. Although its use is } \\
\text { still controversial among authors. }\end{array}$ \\
\hline Cyclosporine & $\begin{array}{l}\text { Cyclosporine is a potent immunossupressive that minimizes IL-2 expression and subsequently minimizes } \\
\text { T cell numbers. Usually microemulsified cyclosporine suspension ( } 2-5 \mathrm{mg} / \mathrm{kg} \text { PO BID) is used. However a } \\
\text { modified cyclosporine has recently been introduced }(7.5-10 \mathrm{mg} / \mathrm{kg} \text { PO SID) and needs to be administrated } \\
\text { in higher dosages to attain proper blood levels }[57,59,61] \text {. }\end{array}$ \\
\hline Feline recombinant interferon omega & $\begin{array}{l}\text { This drug has not displayed adverse effects and is licensed to treat retroviral infections. Studies have shown } \\
\text { that interferon delivered transmucosally was as effective as prednisolone in decreasing clinical signs [57, 59] }\end{array}$ \\
\hline CO2 laser therapy & $\begin{array}{l}\text { The purpose of this therapy is to carbonize inflamed tissue, resulting in the formation of scar tissue. This } \\
\text { scar tissue is considerably less likely to become inflamed over time. This therapy may be repeated in } \\
4 \text { to } 6 \text { weeks, if needed }[57,59,62] \text {. }\end{array}$ \\
\hline
\end{tabular}


Table 5 Clinical trials carried out with mesenchymal stem cells in feline chronic gingivostomatitis

\begin{tabular}{lllll}
\hline Specie (number) & Treatment & Results & Conclusion \\
\hline Cat (7) & Two IV autologous ASCs & Complete remission (3 cats), substantial improvement & Autologous therapy may & [55] \\
& $(\sim 5$ million cells/kg) & (2 cats), no response (2 cats) & be slightly more effective \\
Cat (7) & Two IV allogeneic ASCs & Complete remission (2 cats), substantial improvement & \\
& $(\sim 5$ million cells/kg) & (2 cats), no response (3 cats) & [21] \\
\hline
\end{tabular}

gastrointestinal and immune disorder has proven to be effective and safe [20,67].

Pérez-Merino et al. (2015) [67] carried out a clinical trial with eleven dogs with IBD that had received standard treatment (elimination diet, corticosteroids, antibiotics, antidiarrhoeal and antiparasitic drugs) but did not achieved a satisfactory response (Table 7). These animals went through a period of washout of at least 3 weeks before the trial was undertaken. All dogs received a clinical score using the Clinical Inflammatory Bowel Disease Activity Index (CIBDAI) and the Canine Chronic Enteropathy Clinical Activity Index (CCECAI) scoring system. Every dog was treated with a single ASCs IV infusion $\left(2 \times 10^{6}\right.$ cells $/ \mathrm{kg}$ bodyweight). After 2 weeks of ASCs therapy, a clinical response occurred in all dogs, but clinical remission (defined by a reduction of initial CIBDAI and CCECAI > 75\%) occurred in 9/11 dogs at day 42. The remaining two dogs showed a partial response with an initial reduction of 69.2 and $71.4 \%$ in CIBDAI and CCECAI respectively. In conclusion, the administration of a single IV infusion of allogeneic MSCs was well tolerated by the patients and seemed to produce clinical benefits in dogs with severe IBD.

Another study using MSCs IV therapy in spontaneous feline enteropathy showed a safe and positive clinical response [69] as described in Table 7. Seven cats with diarrhoea for at least 3 months, received two IV injections of $2 \times 10^{6}$ cells $/ \mathrm{kg}$ from cryopreserved feline ASCs, while four cats with a similar clinical condition received saline placebo. Improvement of clinical signs was observed in 5/7 cats that were treated with stem cells after 1 to 2 months, unlike the placebo group which did not display any progress. With this trial it is possible to conclude that MSCs therapy was well tolerated and potentially effective in the treatment of feline chronic enteropathy, although these preliminary results require significant follow-up study.

\section{Feline asthma}

Asthma is a common lower airway inflammatory disease (LAD) in cats that is associated with substantial morbidity and occasional mortality [70, 71]. The word asthma suggests reversible bronchoconstriction and a prevailingly eosinophilic inflammation of the airways and primary symptoms include cough, wheeze and respiratory distress [72, 73].

The main factors responsible for triggering asthma are extensive and complex and they include infectious, environmental, allergic and genetic elements [74]. In cats there is evidence that asthma is mediated by an allergic response after exposure to inhaled aeroallergens. These aeroallergens induce stimulation of a Th2 response and lead to production of a variety of cytokines that trigger molecular switches leading to pathologic changes in airways [70, 72].

Currently there is no curative treatment for feline asthma. Treatment goals consist of reducing airway inflammation, reducing airway hyper reactivity and bronchoconstriction (which relieves airflow limitation), ameliorating airway remodelling and removing the underlying cause, if known [73]. Treatment of acute dyspnea associated with LAD in cats starts with oxygen supplementation and minimal handling/stress reduction. The conventional therapeutic approaches for acute and chronic asthma, described in Table 8, are based on glucocorticoids (which are the gold standard of therapy for reducing airway inflammation) and bronchodilators [70, 73].

Although conventional therapy reduces inflammation and dyspnea in a considerable number of cats, there is still no therapy capable of preventing or reversing all pathological aspects of asthma. Some cats continue resistant to this therapy with persistent clinical signs and eosinophilia in the airways. Other cats are affected by concurrent diseases (e.g. cardiac disease or diabetes mellitus) where the use of glucocorticoids is not advised.

Table 6 Conventional and immunomodulatory therapeutic approach to inflammatory bowel disease

Inflammatory Bowel Disease

First line approach

Sequential treatment trials of parasiticides, an exclusion diet, and antibacterials to exclude known causes of inflammation before the immunosuppressive treatment [63].

Corticosteroids

Oral prednisolone (1 mg/kg BID) $[63,64,68]$

Other immunosuppressive agents

Azathioprine (frequently used in dogs when IBD cannot be effectively managed with glucocorticoids) or cyclosporine (inhibits the production of IL-2) $[63,64,68]$. 
Table 7 Clinical trials carried out with mesenchymal stem cells in canine and feline inflammatory bowel disease

\begin{tabular}{lllll}
\hline Specie (number) & Treatment & Results & Conclusion & Reference \\
\hline Dog (11) & $\begin{array}{l}\text { Single IV allogeneic ASCs } \\
\left(2 \times 10^{6} \text { cells/kg) }\right.\end{array}$ & $\begin{array}{l}\text { After 2 weeks of MSCs therapy, } \\
\text { a clinical response occurred in } \\
\text { all dogs }\end{array}$ & $\begin{array}{l}\text { ASCs was well tolerated and appeared to produce } \\
\text { clinical benefits in dogs and cats with IBD }\end{array}$ \\
[67] \\
Cat (7) & $\begin{array}{l}\text { Two IV allogeneic ASCs } \\
\left(2 \times 10^{6} \text { cells/kg) }\right.\end{array}$ & $\begin{array}{l}\text { Improved clinical signs in 5/7 } \\
\text { MSCs-treated cats }\end{array}$ & [69] \\
\hline
\end{tabular}

This is the reason why we need new therapies for the treatment of asthma [70, 71] namely allergenic-specific immunotherapy, inhibitors of tyrosine kinase, cyclosporine and MSCs therapy (Table 8).

Therapy with MSCs would be ideal given their immunomodulatory abilities (they modulate Th2 lymphocyte activity) and their capability to pass through the lung when administered intravenously [22]. Murine asthma models have demonstrated that stem cells can reduce airway eosinophilia, airway hyper-responsiveness and promote airway remodelling [70]. Two pilot trials carried out in cats have been published to test the efficiency of MSCs therapy. Both trials involved sensitization to Bermuda grass allergen, which resulted in the development of an asthmatic phenotype with airway eosinophilia and airway hyper-responsiveness.

The first study involved six cats with acute asthma, 4/ 6 received five intravenous infusions of allogeneic MSCs (infusions varied between $2 \times 10^{6}$ and $1 \times 10^{7}$ cryopreserved MSCs per cat) and 2/6 received a saline placebo (Table 9). Cats treated with MSCs achieved a decrease in airway eosinophilia and diminished airway hyperresponsiveness at day 133 when compared to the group that was exclusively administrated with placebo. In this trial, lung attenuation and bronchial wall thickness were also assessed by computerized tomography, and it was verified that the score of these parameters was substantially reduced in cats treated with MSCs 9 months later [71].

Table 8 Conventional and immunomodulatory therapeutic approach to feline asthma

\begin{tabular}{|c|c|c|}
\hline & Acute Asthma & Chronic Asthma \\
\hline Glucocorticoids & $\begin{array}{l}\text { Dexamethasone }(0.15-1 \mathrm{mg} / \mathrm{kg} \text { intramuscular } \\
\text { [IM] or IV) is indicated in cats that show signs } \\
\text { of acute dyspnea }[70,73] \text {. }\end{array}$ & $\begin{array}{l}\text { Oral prednisolone }(0.5-1 \mathrm{mg} / \mathrm{kg} \mathrm{BID}) \text { is recommended } \\
\text { for the first } 7 \text { to } 14 \text { days. Once clinical signs are well } \\
\text { controlled, the dose can be gradually reduced over } \\
2 \text { to } 3 \text { months to once a day. } \\
\text { Inhaled fluticasone ( } 110 \mathrm{mcg} \text { BID for } 2 \text { to } 3 \text { weeks) is } \\
\text { an alternative although it is not useful in a crisis } \\
\text { because it takes about } 10 \text { to } 14 \text { days to become } \\
\text { effective and, since pets cannot be trained to inhale } \\
\text { correctly, administration of aerosolized drugs requires } \\
\text { the use of mask. } \\
\text { Injectable methylprednisolone acetate (10-20 mg/cat } \\
\text { IM or SC every } 4 \text { to } 12 \text { weeks) may also be used }[70,73] \text {. }\end{array}$ \\
\hline Bronchodilators & $\begin{array}{l}\text { B2-receptor agonists, such as terbutaline } \\
\text { ( } 0.01 \mathrm{mg} / \mathrm{kg} \mathrm{IM} \text { or } \mathrm{SC}) \text {, or albuterol ( } 90 \mathrm{mcg} \text { inhaled) } \\
\text { to reduce bronchoconstriction and relieve airflow } \\
\text { limitation }[70,73] \text {. }\end{array}$ & $\begin{array}{l}\text { The most generally used are } \beta 2 \text {-receptor agonists, } \\
\text { namely terbutaline }(0.1-0.2 \mathrm{mg} / \mathrm{kg} \text { PO TID or BID), } \\
\text { and less commonly methilxanthine derivates such as } \\
\text { theophylline (the recommended dose of sustained-release } \\
\text { theophylline in cats is } 20 \text { to } 25 \mathrm{mg} / \mathrm{kg} \text { PO SID, and for } \\
\text { non-sustained-release theophylline } 4 \mathrm{mg} / \mathrm{kg} \text { TID or } \\
\text { BID) }[70,73] \text {. }\end{array}$ \\
\hline Allergenic-specific immunotherapy & - & $\begin{array}{l}\text { Intravenous or subcutaneous allergenic-specific } \\
\text { immunotherapy was proved to decrease eosinophilia } \\
\text { airway inflammation and is generally associated with } \\
\text { minimal side effects }[70,75] \text {. }\end{array}$ \\
\hline
\end{tabular}

Inhibitors of tyrosine kinase

Cyclosporine
Inhibitors of tyrosine kinase are small molecules that block ATP-binding site of kinases. During a trial model of feline asthma, this therapy has proven to be efficient in reducing airway inflammation $[68,76]$.

Cyclosporine inhibits T-cell activation and blocks the development of a Th2 phenotype and the associated Th2-eosinophil interactions. In a feline asthma experimental study, Mitchell et al. (1998) [77] demonstrated that cyclosporine did not inhibit the early phase response to allergen challenge, but it was effective at reducing airway hyperresponsiveness to acetylcholine and airway remodeling [78]. 
Table 9 Clinical trials carried out with mesenchymal stem cells in feline asthma

\begin{tabular}{|c|c|c|c|c|}
\hline Species (number) & Treatment & Results & Conclusion & Reference \\
\hline Cat (6) Acute asthma & $\begin{array}{l}\text { Five IV allogeneic ASCs } \\
\text { (varied between } 2 \times 10^{6} \\
\text { and } 1 \times 10^{7} \text { per cat) }\end{array}$ & $\begin{array}{l}\text { Decreased in: airway eosinophilia, } \\
\text { hyper-responsiveness and airway } \\
\text { remodeling }\end{array}$ & $\begin{array}{l}\text { ASCs therapy had a positive } \\
\text { effect on airway remodeling }\end{array}$ & [71] \\
\hline Cat (9) Chronic asthma & $\begin{array}{l}\text { Six IV allogeneic ASCs } \\
\text { (with range amplitude of } \\
0.36-2.5 \times 10^{7} \mathrm{MSCs} / \text { infusion) }\end{array}$ & Decreased in airway remodeling & & [79] \\
\hline
\end{tabular}

The second study involved nine cats with chronic asthma, $5 / 9$ received six intravenous infusions of allogeneic MSCs (with range amplitude of $0.36-2.5 \times 10^{7}$ MSCs/infusion) and 4/9 received a saline placebo (Table 9). Unlike the previous trial, cats suffering from chronic asthma that were treated with MSCs did not experience a decrease in airway eosinophilia and diminished airway hyper-responsiveness compared with placebo group. However, there was a significant reduction in the lung attenuation and in the bronchial wall thickness observed through computerized tomography 8 months after treatment, once again indicating a positive effect on airway remodelling [79].

Therapy with ASCs proved to have a positive effect on remodelling airways in the two pilot trials controlled by placebo and using feline asthma models. Moreover, the results attained from this cell therapy were more favourable when treatment was carried out in an acute stage of the asthma.

\section{Current status and future prospects}

The multipotent and non-teratogenic properties of MSCs led to the conclusion that these cells could be clinically used to regenerate injured tissues and to treat immune-mediated disorders due to their immunomodulatory potential. Over the last few years some researchers have questioned the efficiency of the treatment with stem cells. There is sparse evidence suggesting that the primary function of MSCs is its differentiation in in vivo new tissues, questioning the importance of differentiation to the therapeutic properties of such cells when injected in a naive state $[13,82]$.

There are still several questions concerning the use of MSCs: their immunomodulation mechanism has not yet been completely understood and the combined results of this therapy require a better scientific clarification. The use of allogeneic vs. autologous MSCs therapy might contribute to the differences in efficacy observed in some clinical trials. On the other hand, the in vitro expansion of MSCs before clinical usage might take weeks before it provides enough cells to administrate with therapeutic effect, resulting in loss of stemness [82].

In fact, different routes of administration result in different risks for the patient. Systemic administration can lead to the entrapment of MSCs in the microvasculature or lung, causing dangerous side effects for the patient, such as pulmonary emboli [12]. Also, these cells, once administered, are almost $90 \%$ lost because of physical stress, inflammation, hypoxia, or immunogenic rejection. To reach therapeutic efficacy, a large number of cells may be required, increasing the potential risk of teratoma formation. Therefore, new studies should be carried out in order to define the minimum therapeutic dose of MSCs [12].

In order to overcome these obstacles to treatment, careful evaluation of appropriate cell sources, good quality control systems, standardized protocols for cell culture and their differentiation, expansion and cryopreservation are necessary. Therefore, the regulation mechanism of MSCs to produce soluble factors and the way these factors are capable of modulating cells of the immune system are key questions that underlie the successful immunomodulation effects of MSCs. All these factors combined with genetically modified MSCs might open a way for the development of an effective cell therapy for multiple animal and human immune disorders.

Despite current contradiction found among researchers concerning the efficacy of MSCs, this revision has demonstrated a generally positive result of the use of these cells in the treatment of immune-mediated disorders in veterinary medicine. Even so, MSCs-based therapy is currently requiring, more than ever before, a complete analysis and reconsideration in the hope to overcome its limitations in coming trials. In the future, this approach could be more cost-effective than actual conventional treatments due to the recent development and continuous success regarding MSCs application in immune-mediated diseases.

\section{Conclusions}

MSCs immunomodulatory properties make them a unique cell type capable of repairing tissue and organ injuries caused by chronic inflammation or autoimmune disorders.

According to the results of aforementioned trials, it is possible to verify a positive balance in the use of MSCs for the treatment of FCGS, IBD and feline asthma. Concerning FCGS and IBD, one or two infusions of stem cells were sufficient to attain considerably favourable results, as most of the animals involved experienced improvements of the clinical signs and none of them revealed any adverse effects.

In feline asthma, the clinical trials required a higher number of stem cells infusions (five to six) to provide 


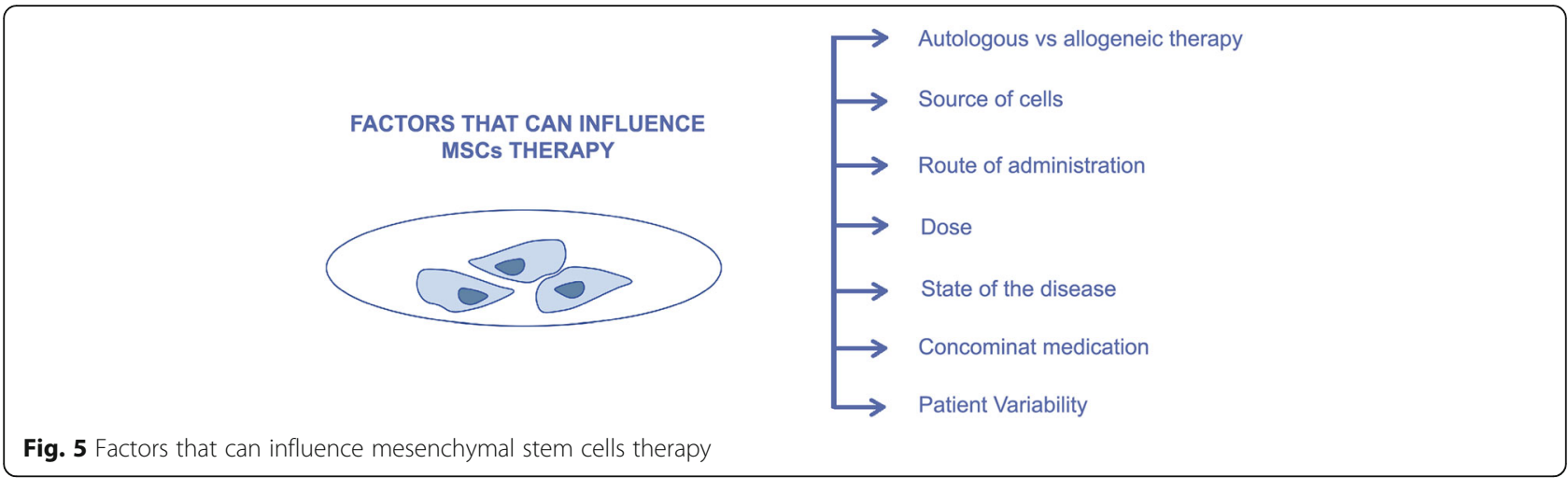

for a proper passage of these cells towards the lung, and the results were equally satisfactory. Furthermore, the results achieved from this cell therapy were more favourable when treatment was carried out with autologous MSCs and in acute asthma.

Canine atopic dermatitis has not displayed results as satisfactory as the other observed diseases. However, only one clinical trial has been carried out in a sample of five dogs, which included a sole IV administration of MSCs at a lower dosage than the dose used in other similar trials. This might be one of the reasons for the failure of the therapy. Meanwhile, there are several unpublished studies that claim success in treating $\mathrm{AD}$ by injecting MSCs both IV and IM on the main areas affected by the disease. Despite this claim, these results still lack validation and standardization of the total number of cells injected, as different studies report using different numbers of cells per $\mathrm{kg}$ of body weight.

Although MSCs can bring a promising future to the treatment of the majority of these disorders, the considerable variability of their quality derived from different donors (autologous vs allogeneic therapy), different tissues, different administration routes, different dosages, individual variability of each patient (e.g. age of the patient) and state of the disease, might limit its therapeutic benefit (Fig. 5).

Canine atopic dermatitis, feline chronic gingivostomatitis, inflammatory bowel disease and feline asthma are relatively common diseases among veterinary medicine, which is why they were widely considered throughout this revision. Nevertheless, the same rational used in these disorders may be applied to several others with a similar immunomediated nature, namely systemic lupus erythematosus, pemphigus foliaceus, perianal fistula and immune mediated cutaneous vasculitis [4, 80, 81]. All these pathologies are characterized by a dysfunction of the immune system with a pathologic response mediated by Th1 cells and inflammatory mediators. Since MSCs are able to suppress the proliferation of $\mathrm{T}$ cells and modulate their response (change the Th1 proinflammatory profile into a Th2 anti-inflammatory profile) through the secretion of several soluble factors or through cell-to-cell contact [38], they will certainly become an important therapeutic approach to treat any of these pathologies. Nevertheless, sufficient clinical trials have not yet been performed to confirm the success and validity of the therapy.

The main obstacle to MSCs therapy is individual and species diversity, and also the inconsistency of protocols applied to date, since there are still very few clinical trials performed in veterinary medicine and most of them have used small samples. Both physicians with expertise in this field and regulatory agencies, need to work together towards the standardization and quality assurance of cellular therapies being applied clinically. The way we practice medicine is changing and evolving rapidly, and although it is difficult to predict where we will be in the near future, cellular therapies certainly seem to have come to stay.

\section{Abbreviations}

AD: Atopic Dermatitis; APMVEAC: Associação Portuguesa de Médicos Veterinários Especialistas em Animais de Companhia; ASC: Adipose-derived Stem Cell; ATP: Adenosine Triphosphate; BID: Bis In Die (In Latin, two times a day); BM: Bone Marrow; BMSC: Bone Marrow-derived Stem Cell;

CCECAl: Canine Chronic Enteropathy Clinical Activity Index; CD: Cluster Differentiation; CIBDAl: Clinical Inflammatory Bowel Disease Activity Index; DCs: Dendritic Cells; ESCs: Embryonic Stem Cells; FCGS: Feline Chronic Gingivostomatitis; FCV: Feline Calicivirus; FDA: Food and Drug Administration; FeLV: Feline Leukemia Virus; FIV: Feline Immunodeficiency Virus; HGF: Hepatocyte Growth Factor; HO: Hemoxygenase; IBD: Inflammatory Bowel Disease; ICADA: International Committee on Allergic Diseases of Animals; IDO: Indolamine 2,3-dioxygenase; IFN-y: Interferon gamma; Ig: Immunoglobulin; IL: Interleukin; IM: Intramuscular; iPSCs: Induced Pluripotent Stem Cells; IV: Intravenous; kg: Kilogram; LAD: Lower Airway Disease; mg: Miligram; mgc: Microgram; MHC-II: Major Histocompability Complex II; MSCs: Mesenchymal Stem Cells; NG2: Neural/Glial antigen 2; NK: Natural Killer; NO: Nitric Oxide; NSAID: Nonsteroidal Anti-Inflammatory Drug; PDGF-Rß: Beta-type Platelet-Derived Growth Factor Receptor; $\mathrm{PGE}_{2}$ : Prostaglandin $\mathrm{E}_{2} ; \mathrm{PO}$ : Per os (In Latin, orally); SC: Subcutaneous; SIBO: Small Intestinal Bacterial Overgrowth; SID: Sem'el In Die (In Latin, once a day); TGF- $\beta$ : Transforming Growth Factor $\beta$; Th1: T helper 1; Th2: T helper 2; TID: Ter In Die (In Latin, three times a day); TLRs: Toll-like Receptors; TNF: Tumor Necrosis Factor

\section{Acknowledgments}

The authors would like to acknowledge Professor Dr. Anabela Almeida for the valuable manuscript feedback and Dr. Magda Pacheco for helping us building original figures. 


\section{Authors' contributions}

IED and PPC were responsible for the bibliographic research and redaction of the manuscript; POP, LCB, CAV and IRD were responsible for the tables, images and critical review of the manuscript; IED was responsible for the creation and adaption of the figures; PPC was responsible for the overall supervision and critical review of the manuscript. All authors have read and approved this manuscript.

\section{Funding}

Not applicable.

\section{Availability of data and materials}

All data generated or analysed during this study are included in this published article [and its additional files].

\section{Ethics approval and consent to participate}

Not applicable

\section{Consent for publication}

Not applicable

\section{Competing interests}

P.P.C. declares to be the founder and CEO of Vetherapy, a biotech company focused on regenerative products. P.P.C. also declares that his company had no influence or involvement with any of the results in analysis in this study. The remaining authors declare that they have no competing interests.

\section{Author details}

${ }^{1}$ CIVG - Vasco da Gama Research Center, Vasco da Gama University School, Av. José R. Sousa Fernandes 197, Campus Universitário - Bloco B, Lordemão, 3020-210 Coimbra, Portugal. ${ }^{2}$ Coimbra University Veterinary Hospital, Av. José R. Sousa Fernandes 197, 3020-210 Coimbra, Portugal. ${ }^{3}$ Department of Veterinary Sciences, School of Agricultural and Veterinary Sciences, University of Trás-os-Montes e Alto Douro, Quinta de Prados, 5000-801 Vila Real, Portugal. '3B's Research Group, I3Bs - Research Institute on Biomaterials, Biodegradables and Biomimetics, University of Minho, Headquarters of the European Institute of Excellence on Tissue Engineering and Regenerative Medicine, AvePark, Parque de Ciência e Tecnologia, Zona Industrial da Gandra, 4805-017 Barco, Guimarães, Portugal. ${ }^{5}$ ICVS/3B's - PT Government Associate Laboratory, 4805-017 Braga/Guimarães, Portugal. 'Vetherapy, 479 St, San Francisco, CA 94103, USA.

\section{Received: 24 April 2019 Accepted: 11 September 2019} Published online: 22 October 2019

\section{References}

1. Ogliari KS, Marinowic D, Brum DE, Loth F. Stem cells in dermatology. An Bras Dermatol. 2014;89(2):286-91.

2. Bogers $\mathrm{SH}$. Cell-based therapies for joint disease in veterinary medicine: what we have learned and what we need to know. Front Vet Sci. 2018:5:1-17.

3. Arnhold S, Elashry MI, Klymiuk MC, Wenisch S. Biological macromolecules and mesenchymal stem cells: basic research for regenerative therapies in veterinary medicine. Int J Biol Macromol. 2019;123:889-99.

4. Jiménez A, Guerrero F. Células madre mesenquimales como nueva terapia en dermatología: conceptos básicos. Rev clínica dermatología Vet. 2017;9:8-18.

5. Harman RJ. Stem cell therapy in veterinary dermatology. Vet Dermatol. 2013;24(1):90-e24.

6. Ayala-cuellar AP, Kang J, Jeung E, Choi K. Roles of mesenchymal stem cells in tissue regeneration and immunomodulation. Biomol Ther. 2019;27(1):25-33.

7. Spencer ND, Gimble JM, Lopez MJ. Mesenchymal stromal cells: past, present, and future. Vet Surg. 2011;40(2):129-39.

8. Paterson YZ, Kafarnik C, Guest DJ. Characterization of companion animal pluripotent stem cells. Cytom Part A. 2017;93(1):137-48.

9. De Bakker E, Van Ryssen B, De Schauwer C, Meyer E. Canine mesenchymal stem cells: state of the art, perspectives as therapy for dogs and as a model for man. Vet Q. 2013;33(4):225-33.

10. Sultana T, Lee $\mathrm{S}$, Yoon H, Lee Jl. Current status of canine umbilical cord blood-derived mesenchymal stem cells in veterinary medicine. Stem Cells Int. 2018;1:1-14.
11. Cebrian-serrano A, Stout T, Dinnyes A. Veterinary applications of induced pluripotent stem cells: regenerative medicine and models for disease? Vet J. 2013;198(1):34-42.

12. Heslop J, Hammond T, Santeramo I, et al. Concise Review : workshop Review: understanding and assessing the risks of stem cell-based therapies. Stem Cells Transl Med. 2015;4:389-400.

13. Klinker MW, Wei C-H. Mesenchymal stem cells in the treatment of inflammatory and autoimmune diseases in experimental animal models. World J Stem Cells. 2015;7(3):556-67.

14. Zhao Q, Ren $H$, Han Z. Mesenchymal stem cells: immunomodulatory capability and clinical potential in immune diseases. J Cell Immunother. 2016;2(1):3-20.

15. Gao F, Chiu SM, Motan DAL, Zhang Z, Chen L, Ji H-L, et al. Mesenchymal stem cells and immunomodulation: current status and future prospects. Cell Death Dis. 2016;7(1):e2062.

16. Friedenstein AJ, Chailakhjan RK, Lalykina KS. The development of fibroblast colonies in monolayer cultures of Guinea-pig bone marrow and spleen cells. Cell Tissue Kinet. 1970;3:393-403.

17. Figueroa FE, Carrión F, Villanueva S, Khoury M. Mesenchymal stem cell treatment for autoimmune diseases: a critical review. Biol Res. 2012;45(3):269-77.

18. Schauwer C, Van de Walle GR, Van Soom A, Meyer E. Mesenchymal stem cell therapy in horses : useful beyond orthopedic injuries ? Vet Q. 2013; 33(4):234-41.

19. Hoffman A, Dow S. Concise Review: stem cell trials using companion animal disease models. Stem Cells Express. 2016;34:1709-29.

20. Pérez-Merino EM, Usón-Casaús JM, Zaragoza-Bayle C, Duque-Carrasco J, Mariñas-Pardo L, Hermida-Prieto M, et al. Safety and efficacy of allogeneic adipose tissue-derived mesenchymal stem cells for treatment of dogs with inflammatory bowel disease: clinical and laboratory outcomes. Vet J. 2015; 206(3):385-90.

21. Arzi B, Clark K, Sundaram A. Therapeutic efficacy of fresh, allogeneic mesenchymal stem cells for severe refractory Gingivostomatitis in Cats. Stem Cells Transl Med. 2017;6:1710-22.

22. Quimby JM, Borjesson DL. Mesenchymal stem cell therapy in cats: current knowledge and future potential. J Feline Med Surg. 2018;20(3):208-16.

23. Carrade DD, Borjesson DL. Immunomodulation by mesenchymal stem cells in veterinary species. Comp Med. 2013;63(3):207-17.

24. De Witte SFH, Franquesa M, Baan CC, Hoogduijn MJ. Toward development of iMesenchymal stem cells for immunomodulatory therapy. Front Immunol. 2016;6(1):1-9.

25. Gonçalves N, Ambrósio C, Piedrahita J. Stem cells and regenerative medicine in domestic and companion animals: a multispecies perspective. Reprod Domest Anim. 2014;49:2-10.

26. Hoogduijn MJ. Are mesenchymal stromal cells immune cells? Arthritis Res Ther. 2015;1:1-7.

27. Glenn JD, Whartenby K. Mesenchymal stem cells: emerging mechanisms of immunomodulation and therapy. World J Stem Cells. 2014;6(5):526-39.

28. Dominici M, Le Blanc K, Mueller I, Slaper-Cortenbach I, Marini FC, Krause DS, et al. Minimal criteria for defining multipotent mesenchymal stromal cells. The International Society for Cellular Therapy position statement. Cytotherapy. 2006;8(4):315-7.

29. Malhotra S, Hu MS, Marshall CD, Leavitt T, Cheung ATM, Gonzalez JG, et al. Mesenchymal stromal cells as cell-based therapeutics for wound healing. Stem Cells Int. 2016;2016:2-7.

30. Bateman ME, Strong AL, McLachlan JA, Burow ME, Bunnell BA. The effects of endocrine disruptors on adipogenesis and osteogenesis in mesenchymal stem cells: a review. Front Endocrinol. 2017;7:1):1-12.

31. Gazdic M, Volarevic V, Arsenijevic N, Stojkovic M. Mesenchymal stem cells: a friend or foe in immune-mediated diseases. Stem Cell Rev Reports. 2015;11(2):280-7.

32. Crisan M, Yap S, Casteilla L, Chen CW, Corselli M, Park TS, et al. A perivascular origin for mesenchymal stem cells in multiple human organs. Cell Stem Cell. 2008;3(3):301-13.

33. Esteves $\mathrm{CL}$, Donadeu FX. Pericytes and their potential in regenerative medicine across species. Cytom Part A. 2018;0:1-10.

34. Feng J, Mantesso A, De BC, Nishiyama A, Sharpe PT. Dual origin of mesenchymal stem cells contributing to organ growth and repair. PNAS. 2011;108(16):6503-8.

35. Peroni JF, Borjesson DL. Anti-inflammatory and immunomodulatory activities of stem cells. Vet Clin North Am - Equine Pract. 2011;27(2):351-62.

36. Li N, Hua J. Interactions between mesenchymal stem cells and the immune system. Cell Mol Life Sci. 2017;74(13):2345-60.

37. Yang S-H, Gao C-Y, Li L, Chang C, Leung PSC, Gershwin ME, et al. The molecular basis of immune regulation in autoimmunity. Clin Sci. 2018;132(1):43-67. 
38. Kim N, Cho S-G. New strategies for overcoming limitations of mesenchymal stem cell-based immune modulation. Int J stem cells. 2015;8(1):54-68.

39. Samsonraj RM, Raghunath M, Nurcombe V, Hui JH, van Wijnen AJ, Cool SM. Concise Review: multifaceted characterization of human mesenchymal stem cells for use in regenerative medicine. Stem Cells Transl Med. 2017;6(12):2173-85.

40. Tizard IR. In: Saunders, editor. Veterinary Immunology An Introduction. 7th ed. Texas: Saunders; 2004.

41. Kim J, Hematti P. Mesenchymal stem cell-educated macrophages: a novel type of alternatively activated macrophages. Natl Institutes Heal. 2009: 37(12):1445-53.

42. Maggini J, Mirkin G, Bognanni I, Holmberg J, Piazzo IM, Can C, et al. Mouse bone marrow-derived mesenchymal stromal cells turn activated macrophages into a regulatory-like profile. PLoS One. 2010;5(2):1-13.

43. Li Y-P, Paczesny S, Lauret E, Poirault S, Bordigoni P, Mekhloufi F, et al. Human mesenchymal stem cells license adult CD34+ Hemopoietic progenitor cells to differentiate into regulatory dendritic cells through activation of the notch pathway. J Immunol. 2008;180(3):1598-608.

44. Spaggiari GM, Capobianco A, Abdelrazik H, Becchetti F, Cristina M, Moretta $L$, et al. Mesenchymal stem cells inhibit natural killer-cell proliferation, cytotoxicity, and cytokine production: role of indoleamine 2,3-dioxygenase and prostaglandin E2. Blood J. 2008;111(3):1327-33.

45. Corcione A, Benvenuto F, Ferretti E, Giunti D, Cappiello V, Risso M, et al. Human mesenchymal stem cells modulate B-cell functions. Blood J. 2006;107(1):367-72.

46. Franquesa M, Hoogduijn MJ, Bestard O, Grinyó JM. Immunomodulatory effect of mesenchymal stem cells on B cells. Front Immunol. 2012;3:1-7.

47. Roque JB, O'Leary CA, Duffy DL, Kyaw-Tanner M, Gharahkhani P, Vogelnest $L$, et al. Atopic dermatitis in West Highland white terriers is associated with a 1.3-Mb region on CFA 17. Immunogenetics. 2012;64(3):209-17.

48. Bizikova P, Pucheu-Haston CM, Eisenschenk MNC, Marsella R, Nuttall T, Review SD. Role of genetics and the environment in the pathogenesis of canine atopic dermatitis. Vet Dermatol. 2015;26(2):1-10.

49. Bizikova P, Santoro D, Marsella R, Nuttall T, Eisenschenk MNC, PucheuHaston CM. Review: clinical and histological manifestations of canine atopic dermatitis. Vet Dermatol. 2015;26(2):1-6.

50. Pucheu-Haston CM, Bizikova P, Marsella R, Santoro D, Nuttall T, Eisenschenk MNC. Review: lymphocytes, cytokines, chemokines and the T-helper 1-T-helper 2 balance in canine atopic dermatitis. Vet Dermatol. 2015;26(2):124-e32.

51. Olivry T, DeBoer DJ, Favrot C, Jackson HA, Mueller RS, Nuttall T, et al. Treatment of canine atopic dermatitis: 2015 updated guidelines from the international committee on allergic diseases of animals (ICADA). BMC Vet Res. 2015;11(1):1-15.

52. Michels GM, Ramsey DS, Walsh KF, Martinon OM, Mahabir SP, Hoevers JD, et al. A blinded, randomized, placebo-controlled, dose determination trial of lokivetmab ( ZTS-00103289 ), a caninized, anti-canine IL-31 monoclonal antibody in client owned dogs with atopic dermatitis. Vet Dermatol. 2016;27(6):1-12.

53. Moyaert H, Van BL, Borowski S, Escalada M, Mahabir SP, Walters RR, et al. A blinded, randomized clinical trial evaluating the efficacy and safety of lokivetmab compared to ciclosporin in client-owned dogs with atopic dermatitis. Vet Dermatol. 2017;28:1-13.

54. Hall MN, Rosenkrantz WS, Hong JH, Griffin CE, Mendelsohn CM. Evaluation of the potential use of adipose-derived mesenchymal stromal cells in the treatment of canine atopic dermatitis: a pilot study. Vet Ther. 2010;11(2):E1-14.

55. Arzi B, Bateman ME, Strong AL, McLachlan JA, Burrow MEBB, Vapniarsky N, Mills-Ko E, Verstraete FJM, Fazel N, et al. Therapeutic efficacy of fresh, autologous mesenchymal stem cells for severe refractory Gingivostomatitis in cats. Stem Cells Transl Med. 2016;5:75-86.

56. Winer JN, Arzi B, Verstraete FJM. Therapeutic Management of Feline Chronic Gingivostomatitis: a systematic Review of the literature. Front Vet Sci. 2016:3:1-10

57. Greenfield B. Chronic feline Gingivostomatitis: Proven Therapeutic Approaches \& new Treatment Options. Today's Vet Pract. 2017;7(1):27-38.

58. Kouki MI, Papadimitriou SA, Psalla D, Kolokotronis A, Rallis TS. Chronic Gingivostomatitis with esophagitis in cats. J Vet Intern Med. 2017;31(6):1673-9.

59. Lommer MJ. Oral inflammation in small animals. Vet Clin North Am - Small Anim Pract. 2013;43(3):555-71.

60. Johnston N. Feline chronic gingivitis stomatitis. Dentalvets. 2015:6:15):1-14

61. Lommer MJ. Efficacy of cyclosporine for chronic, refractory stomatitis in cats: a randomized, placebo-controlled, double-blinded clinical study. J Vet Dent. 2013;30(1):8-17.
62. Lewis JR, Tsugawa AJ, Reiter AM. Use of CO2 laser as an adjunctive treatment for caudal stomatitis in a cat. J Vet Dent. 2007;24(4):240-9.

63. Ettinger SJ. Textbook of veterinary internal medicine. 8th ed. Missouri: Elsevier; 2017.

64. Malewska K, Rychlik A, Nieradka R, Kander M. Treatment of inflammatory bowel disease (IBD) in dogs and cats. Pol J Vet Sci. 2011;14(1):165-71.

65. Dandrieux JRS. Inflammatory bowel disease versus chronic enteropathy in dogs: are they one and the same? J Small Anim Pract. 2016;57:589-99.

66. Ferrer L, Kimbrel EA, Lam A, Falk EB, Zewe C, Juopperi T, et al. Treatment of perianal fistulas with human embryonic stem cell-derived mesenchymal stem cells: a canine model of human fistulizing Crohn's disease. Regen Med. 2016;11(1):33-43.

67. Pérez-Merino EM, Usón-Casaús JM, Duque-Carrasco J, Zaragoza-Bayle C, Mariñas-Pardo L, Hermida-Prieto M, Vilafranca-Compte M, Barrera-Chacón R, Gualtieri M. Safety and efficacy of allogeneic adipose tissue-derived mesenchymal stem cells for treatment of dogs with inflammatory bowel disease: endoscopic and histological outcomes. Vet J. 2015;206:1-23.

68. Simpson KW, Jergens AE. Pitfalls and Progress in the diagnosis and Management of Canine Inflammatory Bowel Disease. Vet Clin North Am Small Anim Pract. 2011:41(2):381-98.

69. Webb TL, Webb CB. Stem cell therapy in cats with chronic enteropathy: a proof-of-concept study. J Feline Med Surg. 2015;17(10):901-8.

70. Trzil JE, Reinero CR. Update on feline asthma. Vet Clin North Am - Small Anim Pract. 2014;44(1):91-105.

71. Trzil JE, Masseau I, Webb TL, Chang C-H, Dodam JR, Liu H, et al. Intravenous adipose-derived mesenchymal stem cell therapy for the treatment of feline asthma: a pilot study. J Feline Med Surg. 2016;18(12):981-90.

72. Reinero CR. Advances in the understanding of pathogenesis, and diagnostics and therapeutics for feline allergic asthma. Vet J. 2011;190(1):28-33.

73. Sharp C. Treatment of feline lower airway disease. Today's Vet Pract. 2014;4(2):28-32

74. Rosenberg HF, Druey KM. Modeling asthma: pitfalls, promises, and the road ahead. J Leukoc Biol. 2018;104:1-8.

75. Lee-Fowler TM, Cohn LA, DeClue AE, Spinka CM, Reinero CR. Evaluation of subcutaneous versus mucosal (intranasal) allergen-specific rush immunotherapy in experimental feline asthma. Vet Immunol Immunopathol. 2009;129:49-56.

76. Lee-Fowler TM, Guntur V, Dodam J, Cohn LA, Declue AE, Reinero CR. The tyrosine kinase inhibitor masitinib blunts airway inflammation and improves associated lung mechanics in a feline model of chronic allergic asthma. Int Arch Allergy Immunol. 2012;158(4):369-74.

77. Mitchell RW, Cozzi P, Ndukwu IM, Spaethe S, Le AR, Padrid PA. Differential effects of cyclosporine a after acute antigen challenge in sensitized cats in vivo and ex vivo. Br J Pharmacol. 1998;123:1198-204.

78. Byers C, Dhupa N. Feline bronchial asthma: treatment. Compend Contin Educ Pract Vet. 2005;27(6):426-32.

79. Trzil JE, Masseau I, Webb TL, Chang C, Dodam JR, Cohn LA, et al. Long term evaluation of mesenchymal stem cell therapy in a feline model of chronic allergic asthma. Natl Institutes Heal. 2014;44(12):1546-57.

80. Berglund AK, Fortier LA, Antczak DF, Schnabel LV. Immunoprivileged no more: measuring the immunogenicity of allogeneic adult mesenchymal stem cells. Stem Cell Res Ther. 2017;8(1):1-7.

81. Jayne D, Tynsall A. Autologous hematopoietic stem cell transplantation for systemic lupus erythematosus. Biol Blood Marrow Transplant. 2004;13:168-76.

82. Jang E, Jeong M, Kim S, Jang K, Kang B-K, Lee DY, et al. Infusion of human bone marrow-derived mesenchymal stem cells alleviates autoimmune nephritis in a lupus model by suppressing follicular helper T-cell development. Cell Transplant. 2016;25(1):1-15.

\section{Publisher's Note}

Springer Nature remains neutral with regard to jurisdictional claims in published maps and institutional affiliations. 